\title{
A Struggle for Survival: Genoese Diplomacy with the Sublime Porte in the Face of Spanish and French Opposition
}

\author{
F. Özden Mercan \\ Bilkent University, Department of History, Ankara/Turkey \\ ozdenmercan@bilkent.edu.tr
}

\begin{abstract}
During the sixteenth century Genoa became a significant ally of the Habsburg Empire. Shared political, commercial, financial, and strategic factors tied the Genoese patricians firmly to Spain. However, their alliance was by no means permanent. The relations between the Genoese and the Spanish crown were not without tensions and conflict. In the mid-sixteenth century, the combination of various factors set the stage for Genoa to reconfigure its alliances in the Mediterranean. Having fallen victim to the Habsburg and Valois conflict and being torn between the two, Genoa was forced to resort to an alternative imperial power, the Ottoman Empire, to protect its integrity and independence, as well as to engage in the Levant trade. This article focuses on this moment of crisis in Genoa and analyzes how it led the Genoese to consider shifting their alliance from the Habsburgs to the Ottomans, who were the former's most compelling rival in the Mediterranean. Although the Genoese endeavor ultimately ended in failure, the idea of a potential alliance with the Ottomans and the efforts Genoa invested in its diplomatic negotiations provides insight into the strategies a small state used to survive at a time when imperial rivalry over the Mediterranean was escalating.
\end{abstract}

\section{Keywords}

Republic of Genoa - Ottoman Empire - diplomacy - Early Modern Alliances Spain - France 


\section{Introduction}

On December 1, 1556, Agostino Pinello Ardimenti, the doge of Genoa, wrote a letter to Sultan Süleyman (r. 1520-1566) expressing the desire of the Republic to gain his favor and to have his consent for Genoese merchants to safely come and trade in the Ottoman lands securely. ${ }^{1}$ In another letter written to Grand Vizier Rüstem Pasha (in office 1544-1553; 1555-1561), the doge repeated the same request, asking for his support concerning negotiations. ${ }^{2}$ Francesco de Franchi (also known as Tortorino), a Genoese resident of Chios and a subject of the sultan, would be sent to the Ottoman capital as Genoa's representative. Preparations for this diplomatic mission were conducted with great care. Various types of woolen and silk fabrics, a velvet robe, a small box of different sorts of confectionaries, six barrels of anchovies, Piacenza cheese, and sugar from the Canary Islands would be sent on a separate ship to Pera. ${ }^{3}$ With these gifts and money de Franchi was to persuade the Ottoman high officials, especially Rüstem Pasha, to grant the Republic's desire for peace and friendship with the Empire.

What was the motive for Genoa to reopen diplomatic contacts with the Sublime Porte after almost a century? The answer to this can be found in the letters of instructions given to de Franchi by the Senate concerning his mission in Istanbul. There were two such letters, one public and one secret. In the public instructions, de Franchi was ordered to make diligent efforts to persuade the Ottoman administration to accede to the Republic's desire for trading privileges in the Ottoman lands. He would do this with the help and favor of Rüstem Pasha, who had precedence over all other ministers at the Porte. Most importantly, his priority should be to gain permission for Genoese ships to obtain grain from Ottoman ports. He was instructed to win the favor of the court officials not only with well-founded arguments but also with small gifts. If Rüstem Pasha vigorously supported the confirmation and, subsequently, the

1 Archivio Stato di Genoa (hereafter ASG), Archivio Segreto (hereafter AS) 2169, Letter of December 1, 1556: "Al Altissimo Potentissimo et Invittissimo e tre mondo S.re Soltan Solyman Gran Imperator di Morsomany." For the topic being discussed here, the records in the box Lettere Ministri Costantinopoli 2169, covering the period 1556-1569, are particularly important. The main difficulty one faces in working with these documents is that they are not organized in chronological or thematic order. Thus, throughout this article, the date of the document will be the main identifier for reference.

2 ASG, AS 2169, Letter of December 1, 1556: "Al Illustrissimo e Eccellissimo S.re, Il S.re Rostem Bassa e Gran Consigliere del Gran Imperator di Morsomany."

3 ASG, AS 2169, Letter of December 20, 1556. 
continuance of the privileges, the Genoese representative was to promise him a life annuity, which would be around 1,000-1,500 scudi per year. ${ }^{4}$

In the secret instructions, de Franchi was commanded to obtain an imperial order from the sultan decreeing that Ottoman galleys should not attack Genoese citizens, ships, or coasts. Moreover, he was provided with the arguments he should use in case of any objections that might be raised by the Ottoman court concerning the Genoese citizens serving Charles v and his son Philip II. De Franchi should make a clear distinction between the Genoese government and those Genoese citizens who were in the service of Spain, explaining that the Republic could not prevent individuals from serving as ministers for the Spanish court or taking up arms against the Ottomans upon the order of the Spanish king. Neither could it prohibit the presence of Spanish ships along the Ligurian coasts, as Spain was far more powerful than Genoa. Thus making it clear that the Genoese government had no responsibility for the antiOttoman acts of Spain's Genoese ministers, de Franchi should also promise the Ottoman administration that the Genoese Republic and nation would not harm the ports and subjects of the sultan. ${ }^{5}$

De Franchi's negotiation with the Ottoman authorities passed off quite successfully; he was able to obtain an imperial order that granted safe conduct for the Genoese diplomatic legate and three ships that would come directly to Istanbul and unload their commodities there. ${ }^{6}$ The prospect of the resumption

4 ASG, AS 2169, Letter of December 1, 1556: "Istruzioni della Signoria a Francesco de Franchi detto Tortolino nella sua prima legazione segreta a Costantinopoli." Some of the documents related to Ottoman-Genoese diplomatic negotiations were published by Camillo Manfroni in 1898. I consulted the original documents in the Genoa State Archive. But throughout the article, the references will be given both to the original sources as well as to Manfroni's transcriptions where necessary. See Camillo Manfroni, "Le Relazioni fra Genova, L'Impero Bizantino e i Turchi," Atti della Società Ligure di Storia Patria 28 (1898), Doc. II, 809-812.

5 ASG, AS 2169, Letter of December 1, 1556: "Istruzioni segrete al Tortolino nella stessa legazione." Manfroni, "Le Relazioni fra Genova, L'Impero Bizantino e i Turchi," Doc. III, 812-813.

6 As mentioned above, Manfroni published part of the documents related to Ottoman-Genoese diplomacy giving reference to Filza AS 2169. Unfortunately, some of the documents in his article are not available in the filza he referred to. However, a number of letters concerning the negotiations and a detailed report on the mission are to be found compiled in a manuscript prepared upon the request of a Genoese nobleman, Tommaso Franzone, in the late seventeenth century and throughout the article I refer to this manuscript: ASG, Biblioteca MS. 128, "Instruttioni e Relationi de Ministri della Ser.ma Rep.ca di Genova, Stati in diversi tempi appresso al Gran Turco ad uso dell' Ill.mo Sig.re Tomaso Fransone." For the letter of the sultan to the doge of Genoa: ASG, Biblioteca Ms. 128, 2v-3r (May 21, 1557): "Traductio litterarum quas scribit Invictissima, Potentissima Imperialis Magnitude Sua Imperator Turcarum ad Ill. mum D. Ducem Nationem de Genua Amicis suis." [Written by Court Dragoman İbrahim]. Manfroni, “Le Relazioni fra Genova, L'Impero Bizantino e i Turchi," Doc. v, 815-816. 
of commercial relations with the Sublime Porte and the suspension of hostility between the two states was welcomed in Genoa, and preparations to send an official ambassadorial retinue to Istanbul got underway.

Unlike its ex-rival Venice, Genoa had not ventured to establish diplomatic representation in Istanbul prior to this attempt in the mid-sixteenth century. In this respect, de Franchi's mission can be considered a surprising diplomatic move on the part of the Republic. But what made Genoa approach the Ottoman court? Why was such an attempt made in 1556 ? In this article, the motives and reasons for the Genoese efforts to revive diplomatic contacts with the Ottoman Empire will be discussed in light of the political and economic developments within Genoa and in the Mediterranean. Considering the fact that Genoa was closely linked to the Spanish Habsburgs after 1528 and followed a course of diplomacy tied to that of Spain, this maneuver in the direction of the Ottoman Empire comes as a surprise, opening the possibility of shifting alliances and new configurations in the Mediterranean, and spurring Spain and France to become actively involved in Genoese diplomacy with the Sublime Porte. In order to understand the politico-economic motives for the Genoese diplomatic contacts with the Ottoman Empire, it is essential to look at the internal dynamics of Genoese politics at the time, as well as the Republic's relations with Spain and France. In the same way, Ottoman attitudes regarding the Genoese initiative require assessment in the context of the political and economic conditions in the Ottoman Empire.

In the historiography, there are very few studies that discuss the reasons behind this diplomatic effort and detail the course of the negotiation process. This could be partly due to a general assumption that Genoa was closely tied to the Spanish Habsburgs and thus any Genoese attempt to negotiate with the Sublime Porte was doomed to failure. From this perspective, the issue was already a cut-and-dried case, not worth in-depth examination. However, the souring relations with the Spanish crown, and economic as well as strategic considerations led Genoa to reconsider the benefits of Spanish protection and look to restore its relations with the Sublime Porte. Thus, the circumstances that stimulated Ottoman-Genoese diplomatic relations were far more complicated than is generally assumed.

In an article that appeared in 1898, Camillo Manfroni discussed the negotiations in detail and published some of the relevant archival documents. ${ }^{7}$ His article laid the groundwork for subsequent exploration of this topic. In

7 Camillo Manfroni, “Le Relazioni fra Genova, L'Impero Bizantino e i Turchi," Atti della Società Ligure di Storia Patria 28 (1898): 577-858. 
recent studies on the history of early modern Genoa, ${ }^{8}$ Ottoman-Genoese diplomatic relations have been mentioned in bits here and there, with reference to Manfroni's work. Yet in his article Manfroni did not discuss the conditions and factors that paved the way for Genoese-Ottoman diplomatic negotiations, rather he put emphasis on the negotiation process itself. More importantly, his article lacks Ottoman perspective. Manfroni minimized the Ottomans' role as active participants in and shapers of the negotiation process. Instead, he overemphasized French influence in Ottoman politics and considered the French input to have been the main determinant of the outcome of the Ottoman-Genoese negotiations. Thus, by bringing the Ottoman context into the picture, this article will evaluate the entire process from a multifaceted perspective and reexamine Genoese-Ottoman diplomatic interactions within a wider context. Such an examination not only sheds light on the factors underlying the Genoese-Ottoman rapprochement but also provides insight into the strategies and machinations that a small state used to survive at a time when imperial rivalry over the Mediterranean was escalating.

\section{8: A Significant Turning Point for Genoa}

In discussing the response of the Italian city-states to the extended political crisis of the late fifteenth and sixteenth centuries, Braudel has argued that each state adopted different strategies regarding these political upheavals in order to maintain their survival:

They might like Genoa in turn surrender, betray, negotiate, lose their identity only to recover it, give or sell themselves to another power; or they might struggle as Florence did, with more passion than lucidity; or as Venice with a superhuman effort managed to do, they might struggle

8 Onorato Pàstine, "Genova e L'Impero Ottomano nel secolo XVII," Atti della Società Ligure di Storia Patria LXXIII (1952): 5-7; Carlo Bitossi, "Genova e I Turchi: Note sui rapporti tra Genovesi e Ottomani fra Medioevo ed Età Moderna," in Italien und Das Osmanische Reich, ed. Franziska Meier (Herne, 2010), 87-117; and James D. Tracy, "Il commercio italiano in territorio ottomano," in Il Rinascimento Italiano e L'Europa, vol. IV: Commercio e cultura mercantile, ed. F. Franceschi, R. Goldthwaite and R. Mueller (Treviso, 2007), 437-438. However, for instance in the very recent studies of the sixteenth-century Genoa by Thomas Kirk and Céline Dauverd, there is no mention of the Genoese-Ottoman diplomatic interactions that took place in the mid-sixteenth century. 
and what was more stand firm. But they all had to adapt; it was the price of survival. ${ }^{9}$

As Braudel notes, the price of survival was not the same for all three states. Moreover, in addition to the human factor, geographical realities played a significant role in determining the political fortunes of these states. For instance, the major threat to Venice was not from other European states, as geographically it enjoyed an isolated position in the Adriatic Sea; rather, it was under threat of the Ottomans expanding towards Venetian zones in the Balkans, the Adriatic and the Eastern Mediterranean. Therefore, the situation of Venice was not unlike that of Florence, which though not a Habsburg satellite was still dependent on the Habsburgs in internal politics and foreign policies; Venice was obliged to maintain a similar kind of balance in its relations with the Ottoman administration. Unlike these two states, Genoa faced a struggle for survival that was more pressing, as due to its location between two rival states, France and Spain, it was more exposed to external threats. In addition, possessed of a seaside geography that offered easy access to the Italian mainland, Genoa served as a gateway to Italy (Jапиа, janua Italiae) and thus became a zone of struggle for dominion in the fifteenth and early sixteenth centuries. ${ }^{10}$

Besides its geographical position, constant internal conflicts and the predominance of individual over state interests made Genoa vulnerable to foreign domination. Instability and upheavals became a characteristic of political life in the city as a result of the incessant rivalry between the nobles (nobili) and the commoners (popolari), the Guelphs and the Ghibellines, and the Adorno and the Fregoso (two families competing for the office of doge). ${ }^{11}$ The competition between the nobles and commoners over public offices and power was only one aspect of the prevailing factionalism. There were also divisions within each group. For instance, among the nobles there was a division between the feudal aristocracy, composed mainly of four major houses (the Doria, the Spinola, the Fieschi, and the Grimaldi), and the faction of ship owners and merchants who had acquired the status of nobility more recently. There was a similar sort of division within the commoners, which were composed

9 Fernand Braudel, The Mediterranean and the Mediterranean World in the Age of Philip II, trans. Siân Reynolds, vol. I (London, 1972), 341.

10 Antonia Borlandi, “Janua, janua Italiae': uno sguardo al Quattrocento Genovese," Archivio Storico Italiano CXLIII, no. 1 (1985): 15-35.

11 Arturo Pacini, "Genoa and Charles V," in The World of Emperor Charles V, ed. Wim Blockmans and Nicolette Mout (Amsterdam, 2004), 169; and Thomas Kirk, Genoa and the Sea: Policy and Power in an Early Modern Maritime Republic, 1559-1684 (Baltimore, 2005), 18-19. 
of two groups: merchants and artisans. These social and political divisions (both horizontal and vertical) prevented any sort of internal unity and coherence in medieval Genoa. ${ }^{12}$ And the factional parties did not hesitate to invite foreign powers to intervene in their internal conflicts. Thus, any power that wanted to gain control over the city made an alliance with either the Fregoso or the Adorno.

Factionalism and dissension began to pose a significant threat to the survival of the state, particularly during the period when the struggle between France and Spain to dominate the Italian peninsula reached its peak. With the help of the papacy and Spain, the Fregoso family took over the office of doge in 1512, but this situation did not last long. Following the collapse of a short-lived alliance with Spain, as of 1515 Genoa was again under the control of France and its new king Francis I. However, in 1522 imperial and papal forces occupied the city, bringing it under Spanish domination once more. In 1527 the French made an initially successful attempt to retake control, besieging Genoa with the help of the Genoese nobleman Andrea Doria; however, French domination quickly ended when Doria switched his allegiance from Francis I to Charles v in $1528 .{ }^{13}$ It can be said that this particular shift of alliance also brought an end to the vicious circle of political instability. With his fleet of twelve galleys, Doria played a strategic role, taking over the city with a coup de main. By means of his naval fleet and assistance from the imperial forces, he drove the French out of Genoa and became captain-general of the imperial fleet. Moreover, he declined to be elected as doge; instead, he supported the establishment of a twelve-member commission that would introduce constitutional reforms. A significant step in this regard was the change in the length of tenure of the office of doge from life to two years. In order to eliminate dissension among different factions, the reforms introduced a new regulation bringing both nobles and commoners together in a single ruling class, giving them all the title of noble and assembling them under twenty-eight alberghi. ${ }^{14}$ These changes brought political stability to the city, albeit temporarily.

12 Kirk, Genoa and the Sea, 23.

13 For a list of the Genoese revolts and changes in government between 1257 and 1528, see Steven A. Epstein, Genoa and the Genoese, 958-1528 (Chapel Hill, 1996), 325-327.

14 The albergo was an association comprising members of various branches of the same family having the same surname, who made a compact among themselves to act as a single entity. The term refers to a "fusion of the families." The names of the alberghi established by the 1528 reforms were: Calvi, Cattaneo, Centurione, Cibo, Cigala, De Franchi, De Marini, Di Negro, Doria, Fieschi, Fornari, Gentile, Giustiniani, Grillo, Grimaldi, Imperiale, Interiano, Lercaro, Lomellini, Negrone, Pallavicino, Pinelli, Promontorio, Salvago, Sauli, Spinola, Usodimare, and Vivaldi. Among them, the De Franchi, Fornari, Giustiniani, Promontorio and Sauli alberghi were from the popolari. Kirk, Genoa and the Sea, 24-25. 
After oscillating between French domination and Spanish protection, Genoa chose the latter as a way to preserve its independence and freedom. The Genoese thus came to regard the emperor as "the protector of all Christianity and particularly of all the cities that want to avoid being subject to others."15 Consequently, the intertwinement of internal and international factors and various political forces impelled the Republic to enter the Spanish-Habsburg imperial system.

\section{A New Period in the Imperial Orbit}

The agreement with Charles $\mathrm{V}$ was based on a guarantee of the liberty of Genoa, restoration of its territorial dominion, and protection from its enemies. In return, Genoa pledged loyalty to the emperor, and Andrea Doria was committed to protecting the imperial possessions from any attacks. By liberating the city from French domination and bringing political stability, Doria had already earned the title of pater patria in Genoa. His close relationship with the emperor further enhanced his reputation; he became a vital link, promoting the bonds between the Republic and the Habsburg Empire. As Pacini noted, it was in every instance stated by the Habsburgs that "any concession granted generally to the Republic or to particular citizens was because of Andrea Doria's intercession and in respect for his services."16 The relationship between Charles v and Doria was based on reciprocal reliance and mutual interest: to Charles, Doria was indispensable for both the naval/military and financial support he could marshal in service of the Habsburgs, while for Doria the benefits and favors he would receive from the emperor were essential to consolidating his power within the city and making him a significant force in Genoese politics. ${ }^{17}$ It was through his agency that other galley owners were contracted with for the Spanish naval force; Doria also had the power to choose which Genoese bankers would serve the emperor's needs. As a result, his command of the imperial fleet and control over financial activities at the Spanish court enhanced his prestige in Genoa, enabling him to establish a clientele network

\footnotetext{
15 Pacini, "Genoa and Charles V," 167.

16 Pacini, “Pignatte di Vetro': Being a Republic in Philip II's Empire," in Spain in Italy, Politics, Society and Religion 1500-1700, ed. Thomas James Dandelet and John A. Marino (Leiden, 2007), 202-203.

17 Pacini, "Genoa and Charles V," 194; and Christine Isom-Verhaaren, Allies with the Infidel: The Ottoman and French Alliance in the Sixteenth Century (London, 2011), 74-76.
} 
among the Genoese elite. ${ }^{18}$ Along with the Doria, the De Mari, Lomellini, Cigala, Imperiale and Negrone operated as galley contractors in the naval battles of the Spanish Habsburgs. ${ }^{19}$

When corsairing activity in the Mediterranean escalated significantly after 1528 , an agreement concerning the provision of galleys was made between the Genoese galley owners and the Habsburg monarchy. Spanish attacks and conquests in North Africa and the Eastern Mediterranean then impelled Sultan Süleyman to improve his navy. The most notable instance of this dynamic occurred when Andrea Doria, as commander of the imperial fleet, attacked Ottoman possessions in Greece in 1532. The sultan thereupon turned to a famous Barbary corsair, Hayreddin, also known as Barbarossa, appointing him grand admiral (kapudan-ı derya) of the Ottoman fleet in $15344^{20}$ The choice of a corsair for this office was not a random one; North Africa-based corsairs such as Barbarossa were a key resource for the Ottoman administration, providing not only the necessary naval technology for the fleet but also expertise, intelligence, and naval bases in the western Mediterranean. ${ }^{21}$ Within a short period, Barbarossa had built up a new Ottoman fleet, being composed of seventyeighty galleys, and began conducting naval expeditions, targeting Habsburg domains in southern Italy and the Ligurian coasts. ${ }^{22}$ Defending against them were the Genoese galleys commanded by Doria. Thus, both Andrea Doria and Hayreddin Barbarossa were able to further their own interests and gain power and wealth in return for meeting the naval needs of their imperial sovereigns. As naval warfare became a significant part of the imperial rivalry in the

18 Kirk, "Giovanni Andrea Doria: Citizen of Genoa, Prince of Melfi, Agent of King Philip II of Spain," in Double Agents: Cultural and Political Brokerage in Early Modern Europe, ed. Marika Keblusek and Badeloch Vera Noldus (Leiden, 2011), 6o-61.

19 Pacini, "Genoa and Charles V," 185; and Giorgio Doria, "Conoscenza del mercato e sistema informativo: il know-how dei mercati-finanzieri genovesi nei secoli XVI e XVII," in Nobiltà e investimenti a Genova in Età Moderna (Genova, 1995), 100.

20 Seyyid Muradî, Gazavat-ı Hayreddin Paşa (MS 2639 Istanbul University), ed. Mustafa Yıldız (Aachen, 1993), 313a.

21 Emrah Safa Gürkan, "The Centre and the Frontier: Ottoman Corporation with the North African Corsairs in the Sixteenth Century," Turkish Historical Review 1 (2010): 133-135. Because of their knowledge and experience, corsairs were considered ideal for the position of grand admiral by the Ottoman intellectuals of the time. For instance, according to Kâtib Çelebi, a seventeenth-century Ottoman scholar, only a corsair should be a grand admiral; even if he did not have a corsairing background, he should consult and take advice from the corsairs in naval affairs. Kâtib Çelebi, Tuhfetü'l-Kibâr Fî Esfâri'l-Bihâr, ed. Orhan Şaik Gökyay (İstanbul, 1973), 235-236.

22 Seyyid Muradî, Gazavat-ı Hayreddin Paşa, 313a-313b. 
Mediterranean between the Habsburgs and the Ottomans during this period, the service of these grand admirals was indispensable. ${ }^{23}$

Despite Genoa's professed neutrality and independence, the realities of the situation with Genoese galleys serving the Spanish kings and Andrea Doria commanding the Spanish fleet made the Republic an enemy of the Ottomans. The Genoese became the "chief informal actors" in the Ottoman-Habsburg wars. ${ }^{24}$ And so, Genoese ships, ports, and coasts became potential targets for the Ottomans in their battle with the Spanish Habsburgs. From this perspective, Genoa's alliance with the Habsburgs was not without consequences; yet, the benefits outweighed the drawbacks. Contracting galleys to the service of the king proved to be a lucrative business for the Genoese nobles. ${ }^{25} \mathrm{In}$ addition to receiving payments in cash, the Genoese were recompensed for their services by means of certain benefits, including extensive trading privileges and tax exemptions in the Habsburg domains. ${ }^{26}$ Similarly, Genoese merchant bankers who provided credits for the emperor to run his realm and finance his wars were reimbursed through certain concessions, such as the right to collect taxes and "issu[e] annuities on various entries of the royal income."27

Looking at the totality of these interactions, Dauverd concluded that there was a symbiotic relationship between Spain and Genoa during the sixteenth century: "the dynastic imperialism of Spain and the mercantile imperialism

23 Christine Isom-Verhaaren, Allies with the Infidel, 72-76.

24 Céline Dauverd, Imperial Ambition in the Early Modern Mediterranean: Genoese Merchants and the Spanish Crown (New York, 2015), 250.

25 For instance, Andrea Doria put his twelve galleys at the disposal of Charles $\mathrm{v}$ in return for 72,000 ducats per year, a supplementary payment for munitions (around 1,200 ducats per year), and certain benefits in Naples, which brought in at least 8,0oo ducats a year. Pacini, "La repubblica di Genova nel secolo XVI," in Storia di Genova: Mediterraneo, Europa, Atlantico, ed. Dino Puncuh (Genova, 2003), 352. In 1530 the number of the galleys rented from Doria rose to fifteen in return for a fee of 90,00o ducats. In 1533, Genoese galleys in the service of the emperor numbered twenty-seven; in 1535, twenty-five Genoese galleys (seventeen belonging to Doria and eight to other Genoese) participated in the Habsburgs' Tunis expedition. Twenty-eight galleys (all belonging to the Doria family) took part in the Battle of Preveza in 1538, and for the expedition against Algiers in 1541, thirty-two Genoese galleys (thirty of them from the Doria family and the other two from the Cigala) were present. After the Habsburg defeat, Charles v gave Andrea Doria thirteen galleys in order to compensate the galley owners for their losses. Moreover, the annual rent of the galleys was constantly increased by the Genoese nobles; this resulted in a constant flow of money to Genoa, reaching 120,000-240,000 ducats per year from the 1530 s to the end of the century. Doria, "Conoscenza del mercato e sistema informative," 99-101.

26 Dauverd, Imperial Ambition in the Early Modern Mediterranean, 34.

27 Kirk, Genoa and the Sea, 30. 
of Genoa expanded simultaneously." ${ }^{28}$ However, it was not the government of Genoa but rather private citizens such as the Doria who provided galleys and credit to the emperor and in return exploited the opportunities offered by the Spanish monarchy, thereby furthering their individual and family interests. Not all Genoese were able to become a part of this symbiotic relationship and benefit from these advantages. It was the old nobility, such as the Doria, Spinola, Grimaldi, Pallavicino, and Lomellini families, who monopolized the business of asentistas of galleys and loan contracts. The alliance with Charles $\mathrm{V}$ presented political and economic opportunities to these families, who represented the pro-Spanish group in Genoa. Thus the new nobles, made up mainly of merchants and artisans, emerged as a rival group to the old nobles. In effect, the long-standing factionalism of medieval Genoa was resurrected in a different form during the early modern period. Despite the formation of a single ruling class under the alberghi by means of the reforms of 1528 , there emerged division within their ranks between the vecchi (old nobles) and the nuovi (new nobles). The economic interests of these two groups began to diverge, leading to jealousy and enmity as a result of the political and economic developments after 1528. During the mid-sixteenth century, the conflict of interests between the vecchi and the nuovi gained a new vigor, which would culminate in the civil war of 1575 . Instances of this conflict were manifested on various occasions; the most notable was the war of Corsica (1553-1559).

Rivalry over the control of the Mediterranean was, as Abulafia has argued, more about controlling important coastlines, islands, and ports than battling over the sea itself. ${ }^{29}$ The island of Corsica had strategic value in the western Mediterranean; it did not have extensive land or rich resources but in terms of location it was of inestimable significance for France as a base that served to interrupt communications between the Iberian Peninsula and Spanish possessions in Italy. After Doria's transfer of allegiance from France to Spain, King Francis I made an alliance with the Ottoman sultan and, together with the Ottoman fleets, French ships began to organize periodic expeditions along the southern Italian and Ligurian coasts. ${ }^{30}$ The enmity reached a climax with the attack of the allied Ottoman-French forces on Corsica. With the support of some locals led by a Corsican rebel, Sampiero Corso, the island had been

28 Dauverd, Imperial Ambition in the Early Modern Mediterranean, 2.

29 David Abulafia, The Great Sea: A Human History of the Mediterranean (New York, 2011), XXX-XXXI.

30 Regarding the initial French-Ottoman expeditions, see Lütfi Paşa, Tevârih-i Âl-i Osman, ed. Kayhan Atik (Ankara, 2001), 277-278. 
occupied and a large part of it taken under the French control as of the end of 1553 . This was a great shock for Genoa, as it posed a strategically significant threat to the city and its environs. The Genoese undertook a long and costly struggle to re-take the island; they were only able to recover it in 1559, with the Treaty of Cateau-Cambrésis. Meanwhile, the Corsica experience had incited new tensions among the ruling elite.

In such a time of crisis, the nuovi had found an opportunity to reassert their influence and policies. For them, the dependence on the Spanish imperial authority for the defense of the Republic's coasts and vital bases was the main source of the problem. As Genoa lacked state-owned galleys, it depended on galleys belonging to private shipowners, many of which were in the service of Charles v. The fact that the monarchy remained indifferent to the gravity of the situation and was quite slow to take action during the conquest of Corsica elicited a negative reaction from the new nobles. Andrea Doria also came in for a share of the criticisms; he was accused of prioritizing his personal interests over the public good. Thus the war of Corsica was used as a pretext by the nuovi to mount a political attack on the vecchi. ${ }^{31}$

It was during this period that Genoese-Ottoman relations experienced a new beginning. When the stabilizing effect of the Spanish alliance began to diminish and the attacks of the allied French-Ottoman forces in Liguria grew more pressing, the possibility of negotiating with the Sublime Porte entered the equation. The faction of the new nobility was certainly influential in initiating diplomatic contacts with the Ottoman Empire in 1556; however, the impetus for such contacts cannot be attributed to factional dynamics alone. A succession of severe famines and difficulty in getting access to grain roused great despair and anger among the populace. To this was added Charles v's delay in paying the galley contractors and shipowners, and finally his bankruptcy in 1557. These financial issues created discontent among some bankers and led to episodes of serious distrust and uncertainty regarding the emperor even on the part of the pro-Spanish faction in Genoa. Thus, all of the above factors-with the urgent need to obtain grain for Genoa coming first and foremost - seem to have influenced the Republic to change course vis-à-vis the Sublime Porte.

31 Arturo Pacini, "La repubblica di Genova nel secolo XVI," 364; and Michel Balard, "Genoese Naval Forces in the Mediterranean during the Fifteenth and Sixteenth Centuries," in War at Sea in the Middle Ages and the Renaissance, ed. John B. Hattendorf and Richard W. Unger (Woodbridge, 2003), 137-149. 


\section{Grain Crisis: A City on the Verge of Famine}

As a coastal city located between the sea and the mountains, Genoa's topographical setting was not suitable for agricultural activities. The lack of arable lands made the city dependent on external resources for its food supply, and for grain in particular. During the medieval period, a significant part of the grain needed was provided by the Genoese colonies in the Eastern Mediterranean; in the sixteenth century, however, it was largely procured from the lands controlled by the Spanish crown. Following the Spanish alliance in 1528, the agreement concluded with Andrea Doria guaranteed privileges that included the provision of Sicilian grain for his navy. In addition, it affirmed that grain would be provided to Genoa from Spanish Habsburg domains such as the kingdom of Naples and Sicily, but with the stipulation that this should not be to the detriment of the local population. ${ }^{32}$ Thus, in return for the services provided by Doria, the Republic was granted the privilege to import grain from southern Italy, which became one of the main sources of grain for Genoa during the sixteenth century.

Being heavily dependent on foreign harvests, however, the Republic was compelled to maintain links with additional grain markets. In addition to that obtained from Sicily and Naples, the Genoese imported grain from France and the Ottoman Empire; but Genoese politics and foreign relations significantly affected the supply from those alternative sources. For instance, after 1528, Genoa was deprived of Provençal grain as a result of the French prohibition on trade. In 1541 a short-term peace with King Francis I came about, and the Genoese were able to meet some of their need for grain from French sources, until the war of Corsica broke out in 1553. Another source of grain was the Levant. During years of poor harvests in Sicily, the Genoese turned to the Ottoman market. ${ }^{33}$ However, the Republic did not negotiate treaties with the Ottomans regarding the trade of grain; rather, they obtained it either through Chios, which became the main center of Genoese trading operations in the

32 Edoardo Grendi, “Genova alla metà del Cinquecento: una politica del grano?" in La repubblica aristocratica dei genovesi: Politica, carità e commercio fra Cinque e Seicento (Bologna, 1987), 174 .

33 For instance, in 1550-51, 186,600 mine of grain were imported from the Orient; in 1551-52, the amount was 175,000 mine; in 1557-58, 95,000 mine; and in 1558-59 60,000 mine. The mine was a unit of measure for grain. In 1550 , a mine Genovese corresponded to approximately 87 kg. Grendi, "Genova alla metà del Cinquecento," 218, fn. 8. 
Levant, or through the mediation of Ragusan merchants, who were quite active in trade between the eastern and western Mediterranean during this period. ${ }^{34}$

As a result of various political and diplomatic crises, during the years 1553 to 1558 Genoa intermittently experienced serious shortages of grain, bringing the city face to face with famine. This was due in large part to frequent grain shortages in Sicily as a result of bad harvests, leading to significant restrictions on its export. The situation regarding Naples was no different. During the period 1556-1558, poor harvests and grain shortages in Naples caused the viceroy to contravene the privileges of the Genoese to export grain to Genoa. The Genoese were angered by this act and responded to the embargo by threatening to apply similar measures against Spanish transactions in Genoa. ${ }^{35}$ This crisis became a breaking point in the relations between Genoa and the Spanish Habsburgs, at the same time unearthing long-hidden tensions between the Genoese and the viceroys of Sicily and Naples.

The grain crisis with southern Italy became a matter of life and death for the Genoese when they could not obtain grain from their alternative suppliers either. France had already renewed hostilities in 1553 with the war of Corsica, and so Provençal grain was no longer available. Although there was ample grain in Andalusia, access via the Tyrrhenian Sea was interrupted significantly due to the Franco-Ottoman takeover in Corsica. ${ }^{36}$ More importantly, the possibility of being supplied by the Ragusans was also hindered by French intervention. In August 1555, the Genoese government wrote that if deprived of grain from Sicily and the Levant, the city would be surrendered: "as far as we are informed, the French have ensured that some ships, and mostly those of the Ragusans transporting goods from the Levant, are not able to carry grain from the east for the Genoese." 37 The last straw was the fate of two Genoese ships loaded with 11,000 mine of Ottoman grain in the autumn of 1555, which Bernardino Mendoza (captain general of Spanish galleys) seized and sent to Livorno and Porto Ercole. ${ }^{38}$ The prolonged famine turned into a crisis, impelling the Genoese government to find new solutions for the problem.

The peace of Vaucelles (in February 1556) between Philip II and Henry II of France temporarily relieved the grain crisis in Genoa, as grain from Provence

34 Braudel, The Mediterranean and the Mediterranean World, vol. I: 343; and James D. Tracy, "Il commercio italiano in territorio ottomano," 433.

35 Céline Dauverd, "The Genoese in the Kingdom of Naples: Between Viceroys' Buon Governo and Habsburg Expansion," in Génova y la Monarquía Hispánica (1528-1713), vol. I, ed. M. H. Sanchez, Y. R. Garfia, C. Bitossi and D. Puncuh (Genova, 2011), 286.

36 Grendi, "Genova alla metà del Cinquecento," 174.

37 ASG, AS 2519, Letter of August 2, 1555.

38 Grendi, “Genova alla metà del Cinquecento," 211. 
and Languedoc became available again. However, regularly frustrated in its requests to the courts of Charles $\mathrm{v}$ and Philip II, disgruntled by the conflicts with the Spanish viceroys in southern Italy and pressured by the French-Ottoman attacks along the Ligurian coast, Genoa decided to apply to the Sublime Porte for access to grain and in 1556 sent Francesco de Franchi to Istanbul to negotiate peace and trade privileges with Rüstem Pasha. Moreover, the Genoese governors instructed the official diplomatic legate to Istanbul to attempt to obtain the sultan's permission for the Republic to send twenty-five to thirty ships to the Levant every year to buy grain. ${ }^{39}$ In this way, the Republic hoped to secure Ottoman grain for Genoa on an official and permanent basis. Thus, the desperate need for grain was undoubtedly at least one important reason for the Republic's attempt to launch diplomatic contacts with the Porte. Alongside the palpable necessity for grain, the idea of reviving trade activities in the Eastern Mediterranean and expanding into the Ottoman market seems to have encouraged the Genoese, particularly the nuovi faction, to negotiate with the Sublime Porte.

\section{Seeking a Place in the Ottoman Market}

It could be argued that the Republic looked to extend its trading operations to new markets in order to increase its gains. As indicated in the letters sent by the doge to the Ottoman administration, the Genoese wanted their ships to trade and navigate freely in Ottoman waters. In other words, they wanted to revive their trading activities in the Eastern Mediterranean and carve out a niche for themselves in the Levant trade. In so doing, they would once more assume the role that they had occupied during the medieval period as intermediary between East and West. But this time, they aimed to connect not only northern European but also Atlantic and Spanish markets to the Levant. In fact, among the gifts presented to the sultan by the Genoese, we see sugar from the Canary Islands as well as various sorts of woolen and silk fabrics. The hoped-for peace treaty with the Ottomans would not only provide security for Genoese merchant ships in the Mediterranean but also enable them to enter the Ottoman market with Genoese textiles.

During the audience given to the Genoese envoys at the Ottoman court, Rüstem Pasha asked in detail what kind of goods the Genoese would bring to the Ottoman Empire to which Genoese ambassador Giovanni de Franchi responded that unlike the Venetians, who brought glass, the Genoese merchants

39 ASG, Biblioteca Ms. 128, “Istruzione per Costantinopoli," 8v (April 25, 1558). 
would bring woolen and silk fabrics as well as gold coins to buy merchandise from the Ottoman domains. He added that if the sultan granted privileges to Genoa, the Genoese would give priority to manufacturing textiles (specifically woolen cloth) for the Ottoman market, as had been the case in the past. ${ }^{40}$ It should be noted that in the view of the Ottoman administration, European merchants posed a threat when they tried to obtain and export from Ottoman lands commodities that were vital or militarily important for the empire. As long as these merchants brought goods into the Ottoman market that could facilitate the provisioning of the court and army, they were welcomed. Gold and silver in particular were favored as important sustenance of war. ${ }^{41}$ The grand vizier thus regarded with favor the commodities that the Genoese representatives proposed to bring to the Ottoman Empire.

Mired between Spanish and French impediments, the Genoese mission at the Ottoman court had a thorny path from the very beginning. Initial diplomatic success was owed to Francesco de Franchi, who had successfully negotiated with the Ottoman court and reopened official diplomatic contact between the two states in 1556 . He was able to obtain an imperial order that granted safe conduct for the Genoese diplomatic legate. ${ }^{42}$ However, misfortune struck de Franchi on his way back to Genoa. He was captured and imprisoned by the Spanish ministers governing Calabria, and all the official documents he carried, including the sultan's letter, were confiscated. ${ }^{43} \mathrm{He}$ was able to come back to Genoa only in November 1557, almost a year after his departure.

Not only Spain, but also France actively opposed de Franchi's mission at the Porte. When Jean Cavenac de la Vigne, the French ambassador in Istanbul, received the news of the arrival of the Genoese representative, he wrote to Henry II, reporting that he negotiated with the sultan charging the Genoese with all manner of crimes. With such accusations, de la Vigne intended to provoke the sultan against the Genoese Chiots, accusing them of spying for the enemies of the sultan and putting Chios at the target of the sultan on the eve

40 ASG, Biblioteca Ms. 128, 17v-18r; Manfroni, "Le Relazioni fra Genova, L'Impero Bizantino e i Turchi," Doc. Xxi / Parte I, 839 .

41 Suraiya Faroqhi, "Before 1600: Ottoman Attitudes towards Merchants from Latin Christendom," Turcica 34 (2002): 99.

42 ASG, Biblioteca Ms. 128, 2v-3r (May 21, 1557); Manfroni, "Le Relazioni fra Genova, L'Impero Bizantino e i Turchi," Doc. v, 815 .

43 ASG, AS 2169, Letter of June 20, 1558 Manfroni, "Le Relazioni fra Genova, L'Impero Bizantino e i Turchi," Doc. XI, 823 . 
of the diplomatic negotiations between the Porte and the Republic. ${ }^{44}$ Thus, it took almost a year for the Republic to send an official diplomatic legation to Istanbul. In the late spring of 1558 Genoese representatives-Giovanni de Franchi as ambassador and Niccolò Grillo as future bailo - were finally sent to the Porte. Up to this point, the main emphasis has been on the motives and justifications of Genoa in initiating this diplomatic endeavor. What, then, about the Ottoman side? Why did the Sublime Porte agree to negotiate capitulations with the Republic, a close ally of its fiercest rival?

\section{Ottoman Foreign Policy in the Mid-Sixteenth Century}

The apparent Genoese-Ottoman convergence was prompted both by economic interests and by specific political considerations. At around the same time as the Genoese negotiations were taking place, the Sublime Porte was dealing with an internal crisis. Sultan Süleyman's sons Bayezid and Selim were already at loggerheads with each other over the succession to the throne, a situation that after 1558 turned into a war. The sultan openly supported Selim as his successor. Bayezid, aware of the doom awaiting him, decided to flee and took shelter in Persia, leading to that state's involvement in the conflict. Thus the crisis precipitated by a runaway Ottoman prince fueled the existing rivalry between the Ottoman Empire and Safavid Persia for domination over the region and the trade routes connecting Europe with Asia. Shah Tahmasp tried to use the Bayezid issue to further his own interests, but in the end he agreed to return the prince, and in 1562 Bayezid was executed in Iran by an Ottoman agent working for Selim. ${ }^{45}$ The Bayezid affair, lasting from 1558 to 1562 , significantly constrained the Ottoman government in its relations with other foreign powers. ${ }^{46}$ During this period, peace negotiations took place with the Holy Roman Empire, Genoa, Florence, and Spain as well as with the Safavids. Ambassador Busbecq, who came to the Ottoman capital in 1555 as representative of the Holy Roman Emperor, initially experienced some difficulties; however, he was able to conclude a six-year truce with the Ottomans in 1562. Genoa and Florence sent diplomatic representatives to the Ottoman capital in

44 Ernest Charrière, Négociations de La France dans le Levant, vol. II (Paris, 1850), 391-392, Letter of M. de la Vigne to Henry II (May 15, 1557).

45 Şerafettin Turan, Kanuni Süleyman Dönemi Taht Kavgaları (Ankara, 1997), 48-114.

46 Kaya Şahin, Empire and Power in the Reign of Süleyman. Narrating the Sixteenth-Century Ottoman World (Cambridge, 2013), 147. 
1556-1557 to obtain peace and trade treaties. Spain soon followed suit, initiating informal diplomatic contacts with the Ottoman government in 1558 .

The Ottomans' actions were influenced not only by the succession crisis between the sultan's sons, but by Grand Vizier Rüstem Pasha's choice of policy. The mid-sixteenth century was a period of transformation for the Ottoman Empire in terms of administrative structure as well as political, economic, and cultural policies. Unlike the first part of Sultan Süleyman's reign, which was characterized by the rivalry with Charles $\mathrm{V}$ over universal rulership and territorial expansion, the second half of his reign focused more on internal consolidation and an expansion of the central bureaucracy. ${ }^{47}$ In relation to these efforts, an important change was the empowerment of the office of grand vizier. As Sultan Süleyman withdrew himself more and more from daily politics and active governing, the grand vizier took over these duties as the deputy of the sultan. As an influential and long-serving figure at the Ottoman court, Grand Vizier Rüstem Pasha had a significant role in this transformation process. Through his abilities and his marriage with the sultan's only daughter, Rüstem was able to maintain the favor of the sultan and enhance his authority in the administration of the empire. He favored peace in foreign relations and received positively the requests of other powers for friendship; ${ }^{48}$ this allowed for closer diplomatic contacts with former enemies, including Genoa and Spain, during this period. In diplomatic negotiations, he became the main negotiator and sole authority acting on behalf of the sultan; in the words of Venetian bailo Nicolò Michiel, Rüstem was a second Süleyman. ${ }^{49}$ The Genoese governors were also aware that Rüstem Pasha enjoyed significant diplomatic power at the court. They not only held him in great respect and esteem but also offered to pay him a personal tribute annually if the desired capitulations, especially the privilege of obtaining grain from the Ottoman domains, were granted. ${ }^{50}$

47 Cornell Fleischer, "The Lawgiver as Messiah: The Making of the Imperial Image in the Reign of Süleyman," in Soliman Le Magnifique et Son Temps, ed. Gilles Veinstein (Paris, 1992), 159-177; and M. Zahit Atçl, "State and Government in the Mid-Sixteenth Century Ottoman Empire: The Grand Vizierates of Rüstem Pasha (1544-1561)" (Ph.D. Diss., The University of Chicago, 2015).

48 Halil İnalcık, "Sultan Süleyman: The Man and the Statesman," in Soliman Le Magnifique et Son Temps, ed. by Gilles Veinstein (Paris, 1992), 94.

49 Nicolò Michiel, "Viaggio e Relazione (1558)," in Relazioni di Ambasciatori Veneti al Senato: Costantinopoli, Relazioni Inedite (1512-1789), ed. Maria Pia Pedani-Fabris (Padova, 1996), 108-109.

50 ASG, AS 2169, Letter of December 1, 1556: "Istruzioni della Signoria a Francesco de Franchi detto Tortolino nella sua prima legazione segreta a Costantinopoli”; Camillo Manfroni, "Le Relazioni fra Genova, L'Impero Bizantino e i Turchi." 
During the mid-sixteenth century, grain was one of the commodities that was most carefully supervised and regulated in the Ottoman Empire. Storage of grain was organized by the state and oversight of all food supplies came under the authority of the grand vizier. As maintaining a sufficient supply of grain was vital both for military campaigns and for feeding the populace, its export from Ottoman lands was permitted only through special licenses granted to foreign merchants for one-time use. In cases of scarcity or shortage, the government forbade its sale to European merchants entirely. ${ }^{51}$ Rüstem Pasha himself exercised strict control over grain exports to Europe. Although this may have been partly due to concern about adequately provisioning Istanbul, it was also a result of his personal interests. He actively dealt in trade agreements with European powers; through his agents and ships he sold and delivered grain to the Ragusans and Venetians from his extensive estates in Greece and in the Balkans. ${ }^{22}$ Seeing that the grand vizier played an active role in grain trade, the Genoese sought to gain Rüstem's support in order to secure Ottoman grain officially. And in fact the grand vizier also considered the Genoese request favorably. During an audience at the Ottoman court, Rüstem Pasha interrogated the Genoese ambassadors about their grain resources; the latter replied that they customarily obtained it from Sicily, Milan, and other such places, but when there was scarcity in those regions, they went wherever they could to find it. Upon this, the grand vizier gave the green light for the sale of Ottoman grain to the Genoese as long as the Ottoman capital had a sufficient supply for itself. ${ }^{53}$ The control of grain supplies gave Rüstem significant leverage in diplomatic relations with the Genoese.

51 Lütfi Güçer, "XVI. Yüzyll Sonlarında Osmanlı İmparatorluğu dahilinde hububat ticaretinin tâbi olduğu kayıtlar," İstanbul Üniversitesi İktisat Fakültesi Mecmuası 13, no. 1-4 (1952): 79-98; Palmira Brummett, Ottoman Seapower and Levantine Diplomacy in the Age of Discovery, (Albany, 1994), 124; and Rhoads Murphey, "Provisioning Istanbul: The State and Subsistence in the Early Modern Middle East," in Studies on Ottoman Society and Culture, 16th-18th Centuries (Aldershot, 2007), 217-263.

52 For instance, in 1551 the Ragusans asked the grand vizier for permission to buy grain from his agent in Thessalonika. Similarly, in 1555 they obtained fermans from the grand vizier to buy grain in western Greece. James D. Tracy, "The Grand Vezir and the Small Republic: Dubrovnik and Rüstem Paşa, 1544-1561," Turkish Historical Review 1 (2010): 207. Also see Brummett, Ottoman Seapower and Levantine Diplomacy, 139; and Bruno Simon, "Contribution à l'étude du commerce vénitien dans l'Empire Ottoman au milieu du XVI ${ }^{\mathrm{e}}$ siècle (1558-156o)," Mélanges de l'Ecole française de Rome: Moyen Age, Temps Modernes 96, no. 2 (1984): 1003-1013.

53 ASG, Biblioteca Ms. 128, 17r-v; Manfroni, "Le Relazioni fra Genova, L'Impero Bizantino e i Turchi," Doc. XxI/ Parte I, 839 . 
In addition to Rüstem Pasha's conciliatory approach to foreign relations, his dislike of the French ambassador Jean de la Vigne was also a significant factor causing him to favor rapprochement with the Genoese. The fact that the French ambassador was not able to deal with the grand vizier tactfully had a serious impact on diplomatic relations between the two states. ${ }^{54}$ The close collaboration between the Ottoman Empire and France dated back to 1525, when the forces of Charles v defeated the French and captured Francis I at the Battle of Pavia. France sent an ambassador to Sultan Süleyman, asking for his assistance in saving the French king; the sultan received this request favorably, sowing the seeds of diplomatic relations between the two states. ${ }^{55}$ For France, Sultan Süleyman was the only ally strong enough to stop Habsburg domination over Europe. For the Ottomans, having a Christian ally in Europe would likewise be a strategic advantage in their struggle against the Habsburg Empire. Thus, their shared enmity and opposition to the Habsburgs brought the two powers together to cooperate in alliance against Charles v.

Although it was military and political necessity that prompted frequent diplomatic exchanges between France and the Sublime Porte during this period, military cooperation between the two powers was in fact rarely effective. The naval campaign of the allied forces in 1543-44 achieved nothing, despite extensive and costly preparations. During the reign of Henry II military operations continued, but still did not bring much success. In $155^{2}$ a joint French-Ottoman attack was mounted in the western Mediterranean; however, due to lack of coordination, it ended in failure. The following year the target for the joint French-Ottoman forces was Corsica and by extension its overlord Genoa. However, the Ottomans were already engaged in conflict on their eastern front and had no wish to enter into a war with the Spanish Habsburgs in the west. Therefore, the island could not be taken over in its entirety. ${ }^{56}$ In view of these outcomes, the French-Ottoman expeditions can be considered largely ineffectual.

Besides the lack of military coordination, collaboration between the two powers was also at times hampered by a lack of cordiality in the relations between French officials and Ottoman notables. Reciprocal distrust and various

54 Among the contemporary accounts, Ambassador Busbecq's letters provide detailed information about the relationship between the grand vizier and the French ambassador. Ogier de Busbecq, Turkish Letters (London, 2001), 135-136.

55 Kemal Paşazâde, Tevârih-i Âl-i Osman, X. Defter, ed. Şefaettin Severcan (Ankara, 1996), 220-221.

56 Christine Isom-Verhaaren, Allies with the Infidel, 42-43; De Lamar Jensen, "The Ottoman Turks in Sixteenth Century French Diplomacy," The Sixteenth Century Journal 16, no. 4 (1985): 458-459. 
conflicts in individual relationships tended to prevent effective joint action. For instance, enmity between the French ambassador Jean de la Vigne and Rüstem Pasha had an impact on the allied expedition to the Ligurian coast in $155^{8}$, playing into the hands of the Genoese such that they were able to protect their shores from French-Ottoman attack through diplomatic means. Having heard that Ottoman admiral Piyale Pasha was sailing toward the Ligurian coast, the Republic decided to send Francesco Costa as an extraordinary ambassador to negotiate with the pasha. ${ }^{57}$

Among contemporary Ottoman chronicles, the Chronicle of Rüstem Pasha presents a detailed account of recent Ottoman activities in the Mediterranean as well as some information about the Genoese-Ottoman interactions during this period. ${ }^{58}$ According to this chronicle, the Genoese persuaded the grand admiral not to attack the Ligurian coast, informing him that the sultan had already pledged peace and friendship with the Republic of Genoa. ${ }^{59}$ In the Genoese sources it is indicated that as proof Costa presented Piyale Pasha a copy of the document de Franchi had received from the Porte a year before. ${ }^{60}$ Moreover, by firing salvos to the Ottoman admiral, the Genoese confirmed their subordination and submission to the Ottomans. ${ }^{61}$

Costa's operation was in itself a success, as Piyale Pasha avoided any confrontation with the Genoese. The Genoese legation, on the other hand, was not equally successful during its negotiations in the Ottoman capital. However favorably the Genoese were received at the Porte to begin with, they soon had to return to Genoa empty-handed.

It seems that the Ottoman administration followed a dual diplomacy in dealing with the French and the Genoese actions during this period. According to a detailed report written by the Genoese on the mission, while Sultan Süleyman was in favor of maintaining the French alliance and continuing

57 ASG, AS 2169, "Istruzioni data Magnifico viro Francisco Costae misso ad classem Turcharum pro rebus publicis," (20 June 1558); Manfroni, "Le Relazioni fra Genova, L'Impero Bizantino e i Turchi," Doc. XI, 822.

58 The Chronicle of Rüstem Pasha or Târih-i Âl-i Osman is a history of the Ottoman Empire starting from the origins of the Turks. It covers the history of Turkish principalities and Ottoman history including Kanuni period. It is attributed to Grand Vizier Rüstem Pasha but recent research has indicated that it was most probably written by another contemporary, historian Matrakçı Nasuh. Hüseyin G. Yurdaydın, "Matrakçı Nasuh'un Hayatı ve Eserleri ile İlgili Yeni Bilgiler," Belleten XXIX (1965): 349-353.

59 Rüstem Paşa, Târih-i Âl-i Osman (The Chronicle of Rüstem Pasha). Österreichische Nationalbibliothek, Cod. Mixt. 339, fol. 283a.

6o ASG, AS 2169, "Copia del'Arze datto a Francesco Costa, mandato all' armata turca."

61 ASG, AS 2169, Letter of the doge to de Franchi and Grillo (July 30, 1558); Manfroni, "Le Relazioni fra Genova, L'Impero Bizantino e i Turchi," Doc. XVIII, 831. 
naval expeditions in the western Mediterranean alongside French forces, Rüstem Pasha tended to have a peace agreement with the Genoese. ${ }^{62}$ In the French sources the situation was reflected as if the grand vizier's interests had conflicted with the sultan's desire but the sultan had the last word, and he refused to grant the Genoese a peace and trade treaty. ${ }^{63}$ In other words, he chose the French alliance over Genoese subservience.

In the Chronicle of Rüstem Pasha, however, there is no implication of such a discord between the sultan and the grand vizier. Rather it is emphasized that the sultan did not want a peace agreement due to the misdeeds and unreliable acts of the Genoese. ${ }^{64}$ Thus despite Genoa's proclaimed neutrality and determination to maintain friendly relations with all powers of the Mediterranean, and its desire to attain a position in the Levant trade equal to that of Venice, the Republic was not able to gain the sultan's trust and favor.

Still, one could argue that through his support of the Genoese negotiations, the grand vizier not only furthered his own interests but also brought the French and the Venetians to heel by instigating rivalry and competition between these states. From this perspective, it could be seen as a successful tactic for the Porte, allowing it to play its trading partners off against each other while also opening the door to potential alternative partners for commerce. Moreover, politically, establishing new alliances and luring the allies of the Spanish Habsburgs to its side would always be in the interest of the Sublime Porte. For Rüstem Pasha, the alliance with Genoa would above all be a significant blow to the military power and defenses of the Spanish Empire, as Genoese galleys made up most of the latter's naval force. Thus, he tended to favor strengthening the Empire's own position in the Mediterranean through new alliances, such as that proposed with Genoa, and maintaining peace on all fronts. However, after encountering the Genoese evasiveness regarding the Republic's relationship with Spain, he also withdrew his support.

Despite the fact that the Genoese diplomatic efforts ended in dismal failure, the Republic gained some benefits from this endeavor. First of all, the Genoese were able, albeit temporarily, to keep Ottoman galleys away from Corsica and the Ligurian coast by preventing any possible alliance with the French navy. Moreover, the Genoese ships that had arrived in Istanbul for the negotiations took advantage of this opportune occasion to load grain from Ottoman ports.

62 ASG, Biblioteca Ms. 128, 2ov; Manfroni, "Le Relazioni fra Genova, L'Impero Bizantino e i Turchi," Doc. XXI/ Parte III, 845 .

63 Ernest Charrière, Négociations de la France dans le Levant, vol. II, 492.

64 Rüstem Paşa, Târih-i Âl-i Osman (The Chronicle of Rüstem Pasha). Österreichische Nationalbibliothek, Cod. Mixt. 339, fol. 284a. 
After the failure of its negotiations with the Sublime Porte, Genoa quickly turned to Spain in order to restore its relations with Philip II. The treaty of Cateau-Cambrésis and the subsequent developments changed the balance of power, making conditions more favorable to Genoese interests. Although in the following years another crisis in Corsica and trading opportunities brought forward the possibility of reopening negotiations with the Ottoman Empire, the Republic remained within the orbit of Spain. At the same time, it maintained unofficial contact with the Porte through a well-developed intelligence system that kept both the Republic and the Spanish crown informed regarding developments in the Ottoman capital and court. Thus the Republic once more endeavored to take refuge under the imperial banner in order to maintain its independence, security, and survival. Nor did the Spanish king have any other choice. In order to maintain his position in the Mediterranean he needed Genoese naval support and financial resources. In short, mutual interests once again brought the two states together.

\section{Conclusion}

In the mid-sixteenth century, various events from grain shortages to crises in Corsica resulted in a cooling of relations with Spain, compelling Genoa to fend for itself. It was at this juncture that the Republic decided to turn to the East and attempted to revivify its Levant trade by opening diplomatic contacts with the Sublime Porte. The agreement with the Ottoman administration had a number of aims, above all obtaining easy access to Ottoman grain and protecting the Genoese coast from allied French-Ottoman forces. Despite its assertion of independence, its proclaimed neutrality, and its ambition of putting itself on the same level as Venice and establishing friendly relations with all the powers of the Mediterranean, Genoa could not prevent itself from remaining a Habsburg satellite, tied in many ways to the Spanish king. Unwilling to challenge Spain openly for fear of losing the privilege of free trade and travel in the Spanish domains, Genoa was torn between its desire for peace with the Porte and its fear of the Spanish king and tried to maintain a balance by courting both sides. The Genoese ambassador's remarks to French ambassador de la Vigne clearly expressed the Republic's viewpoint: "[B]ecause [Genoa] was trading all over the world, it was necessary for it to remain on good terms with all." ${ }^{n 5}$ Thus through

65 ASG, Biblioteca Ms. 128, 19v: "perchè negoticando per tutto il mondo, ne bisognava star ben con tutti."; Manfroni, "Le Relazioni fra Genova, L'Impero Bizantino e i Turchi," Doc. Xxi/ Parte II, 843 . 
adept political and diplomatic maneuvers, the Republic endeavored to protect its interests and guaranteed its survival in the mid-sixteenth century. ${ }^{66}$

66 In 1665, Genoa made another serious effort to restore peace and trading privileges with the Ottoman Empire, sending Gio Agostino Durazzo as ambassador to Istanbul. Unlike the diplomatic initiative in 1558, this later mission was successful, and in 1666 the Genoese obtained the privilege of keeping a resident ambassador in Istanbul and a consul in Smyrna. See Onorato Pàstine, "Genova e L'Impero Ottomano nel secolo XVII," Atti della Società Ligure di Storia Patria LXXIII (1952): 13-185. 